\title{
Isolation of equine peripheral blood stem cells from a Japanese native horse
}

\author{
Shingo ISHIKAWA ${ }^{1}$, Ghie HORINOUGHI ${ }^{1}$, Ryugo MIZOGUGHI ${ }^{1}$, Asuka SENOKUGHI ${ }^{1}$, \\ Rie KAMIKAKIMOTO ${ }^{1}$, Daiki MURATA ${ }^{1}$, Takashi HATAZOE ${ }^{1}$, Teruaki TOZAKI ${ }^{2}$, \\ Kazuhiro MISUMI ${ }^{1}$ and Seiji HOBO ${ }^{1 *}$ \\ ${ }^{1}$ Joint Faculty of Veterinary Medicine, Kagoshima University, Kagoshima 890-0065, Japan \\ ${ }^{2}$ Laboratory of Racing Chemistry, Tochigi 320-0851, Japan
}

The sizes of Japanese native horses have drastically decreased, and protection of these populations is important for Japanese horse culture. Social trials as well as scientific attempts are necessary for maintaining the breed. Mesenchymal stem cells (MSCs) have potential as a cell source for various cell therapies. However, there have been no reports on MSCs of Japanese native horses. We aimed to isolate and characterize MSCs from a Japanese native horse, the Noma horse. Plastic-adherent and self-replicating cells were isolated from a Noma horse's peripheral blood (PB). The isolated cells had trilineage potential and a surface antigen of mesenchymal cells, so they fulfilled the minimal criteria of MSCs. Therefore, PB can be one source of MSCs for Japanese native horses.

\author{
J. Equine Sci. \\ Vol. 28, No. 4 \\ pp. 153-158, 2017
}

Key words: Japanese native horse, mesenchymal stem cells, peripheral blood

Japanese native horses have been insulated from other horse populations and actively bred for agriculture, transport, and military purposes. However, with the modernization of human lifestyles and the introduction of alien species, the size of these native horse populations has drastically decreased. The Noma horse is a pony breed originating in Imabari, Ehime Prefecture, and is the smallest horse among Japanese native horses. Like other Japanese native horses, the Noma horse has decreased in number, with the population falling to as low as 5 in the 1970s. To protect these populations, the Noma Pony Preservation Society was formed in 1978 to preserve and promote the breed, and the number of individuals had increased to 84 by 2004. However, in recent years it has again been on a downward trend, declining to 53 by 2016 (Japan Equine Affairs Association; http://www.bajikyo.or.jp). Thus, social trials as well as scientific attempts are necessary for maintaining the breed. Mesenchymal stem cells (MSCs) are adult multipotent stem cells that can differentiate into various lineage

Received: May 19, 2017

Accepted: August 18, 2017

*Corresponding author. e-mail: k2088185@kadai.jp

(C2017 Japanese Society of Equine Science

This is an open-access article distributed under the terms of the Creative Commons Attribution Non-Commercial No Derivatives (by-nc-nd) License. (CC-BY-NC-ND 4.0: https://creativecommons.org/licenses/ by-nc-nd/4.0/) cells $[4,7,9,13,14]$. In addition, since MSCs can secrete cytokines, chemokines, and growth factors that could potentially repair a variety of injuries, they hold promise for use in cell therapy $[14,15]$. Furthermore, since recent studies have demonstrated that MSCs can transdifferentiate into male germ cells, application to species preservation is also expected [17]. In horse medicine, MSCs have been considered to aid in treating various diseases, such as corneal wound and bone cartilage diseases [2, 19]. Bone marrow and adipose tissue derived MSCs are commonly used in horse practice $[3,20]$. However, collection of these cells requires sedation and special procedures [11], and we think this is not suitable for Japanese native horses MSC sources. Recently, it was reported that cells having the same ability as MSCs from peripheral blood (PB-MSCs) were isolated from Western horses such as the Warmblood [5, 12]. PB can be obtained in a simple, safe, and virtually pain-free way. However, there have been no reports regarding PB-MSCs from Japanese native horses, which have a different genetic background from Western horses [23]. In this study, we isolated and propagated fibroblastoid cells from Noma horse PB and investigated the characteristics and multipotency of these cells.

A Noma horse (male, 9 years old) kept for student training at Kagoshima University Veterinary Teaching Hospital was used. The use of animals in our experiments was in accordance with the approved guidelines 

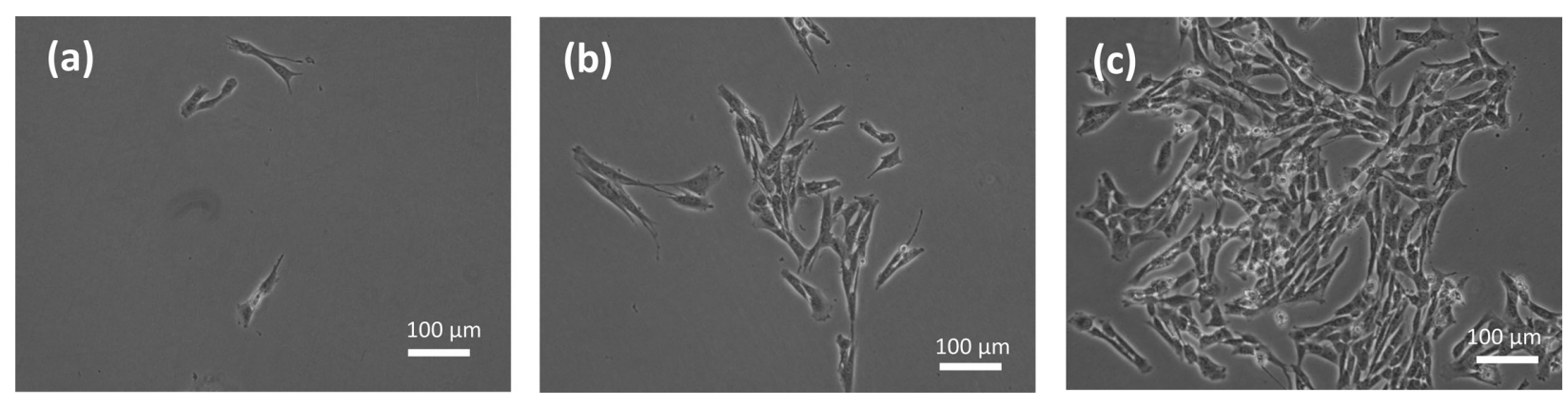

Fig. 1. Morphological appearance of isolated cells after 5 days (a), 7 days (b), and 10 days (c).

(Approval number VM16030) of the Animal Care and Use Committee of Kagoshima University. A venous blood sample $(10 \mathrm{~m} l$ in heparin anticoagulants) was taken from the Noma horse and transported to the laboratory under refrigeration. The mononuclear cells were collected by standard density gradient centrifugation with LympholyteH (Cedarlane, Hornby, Ontario, Canada) according to manufacturer's protocol. The cells were suspended in 10 $\mathrm{m} l$ of proliferation medium (PM) consisting of Dulbecco's modified Eagle's medium (DMEM; Wako Pure Chemical Industries, Osaka, Japan) high glucose, 10\% fetal bovine serum (FBS; Japan Bioserum, Hiroshima, Japan), and 1\% penicillin-streptomycin-amphotericin B solution (Wako). Single-cell suspensions of PB were seeded into $100-\mathrm{mm}$ culture dishes. Cells were seeded at a density of $5.0 \times 10^{5}$ cells $/ \mathrm{cm}^{2}$ and incubated at $37^{\circ} \mathrm{C}$ in humidified $5 \% \mathrm{CO}_{2}$. The $\mathrm{PM}$ was changed to remove non-adherent cells $24 \mathrm{hr}$ later, and the culture was kept under the same conditions. The PM was changed twice weekly. When primary cultures reached $70-80 \%$ confluence, attached cells were released by exposure to $0.25 \%$ trypsin and $1 \mathrm{mM}$ EDTA (Wako) and replated at a density of $6 \times 10^{3}$ cells $/ \mathrm{cm}^{2}$ for subsequent passages. Adherent, spindle-shaped cells were observed at the bottom of the culture dishes after 5 days (Fig. 1a). After 7 days, adherent cells proliferated in several areas of the culture surface (Fig. 1b). After 10 days, proliferated cells developed round colonies in several areas of the culture surface (Fig. 1c). The cells were uniformly distributed immediately after passage, and they formed a homogeneous-appearing population of fibroblast-like cells at the end of the secondary passage. The morphological characters of isolated cells were similar to those of reported horse MSCs [20].

For individual recognition, we performed a microsatellite genotyping assay. Genomic DNA was extracted from passage 3 ePBCs and Noma horse whole blood samples with a DNA Extractor WB Kit (Wako) according to the manufacturer's protocols. Thirty-two microsatellites, which included one set of 18 markers (AHT4, AHT5, ASB2,
ASB17, ASB23, CA425, HMS2, HMS3, HMS6, HMS7, HTG4, HTG10, LEX3, LEX33, TKY19, TKY28, TKY321 and VHL20) and another set of 14 markers (TKY279, TKY287, TKY294, TKY297, TKY301, TKY312, TKY325, TKY333, TKY337, TKY341, TKY343, TKY344, TKY374 and TKY394), were used for the individual recognition in this study. All are used in the Horse Comparison Test of the International Society for Animal Genetics (ISAG), and allele discriminations are based on the consensus of the Equine Genetics and Thoroughbred Parentage Testing by referring to the consensus data of the Horse Comparison Test for STR conducted by ISAG. Microsatellites were genotyped using procedures described by Kakoi et al. [10] and Tozaki et al. [22] with minor modifications. All microsatellites were well amplified and successfully genotyped for DNAs extracted from passage $3 \mathrm{ePBCs}$ and Noma blood samples. Genotypes between the samples completely matched (data not shown). Therefore, it was proved that the isolated cells were derived from the sampled Noma horse.

To demonstrate the proliferation capacity of the cells isolated in this study, cells at passage 3 were seeded in 12 -well plates at a density of 10,000 cells per well. After $24 \mathrm{hr}, 3$ different well were trypsinized daily, counted by a cell counter (Countess, Invitrogen, Eugene, OR, U.S.A.), and averaged from day 1 to day 7 to determine the status of cell growth. Population doubling time (PDT) was calculated as follows: (T-T0) $\log 2 /(\log \mathrm{Nt}-\log \mathrm{N} 0)$, with T0 = starting time of cell culture, $\mathrm{T}=$ ending time of cell culture, $\mathrm{Nt}=$ cell number at the end of culture, and $\mathrm{N} 0=$ cell number at the beginning of culture. A growth curve was determined for passage 3 cells by counting viable cells for 7 continuous days (Fig. 2). After re-seeding, the isolated cells had 2-3 days in the adaptive phase. Then, the isolated cells began to expand rapidly and moved into the logarithmic phase of growth. According to the growth curve, the PDT of the cells from the horses was $23.4 \pm 1.8 \mathrm{hr}$. Since the PDTs of horse MSCs derived from bone marrow and adipose tissue were reported to be almost 2 days [1, 24], the proliferation 


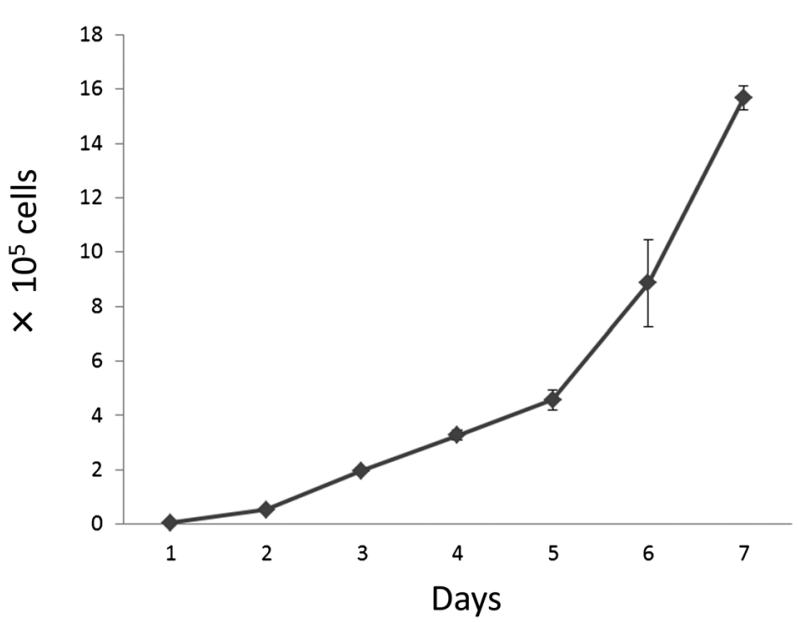

Fig. 2. Growth curve of $P 3$ isolated cells. Results are presented as mean \pm standard deviation of triplicate experiments.

rate of the isolated cells was higher than that in those cells.

To examine trilineage differentiation ability, we performed a culture assay. For osteogenic differentiation, passage 3 isolated cells were plated on 6 -well culture plates at a density of $2.5 \times 10^{3}$ cells $/ \mathrm{cm}^{2}$, and after incubation in PM for $24 \mathrm{hr}$, the medium was changed to osteogenic induction medium (Differentiation Basal Medium-Osteogenic, Lonza, Basel, Switzerland) supplemented with $100 \mu \mathrm{M}$ ascorbic acid, $10 \mathrm{mM} \beta$-glycerophosphate, and $1 \mu \mathrm{M}$ dexamethasone. The medium was changed 3 times per week. Alizarin Red staining was performed to analyze osteogenic differentiation at 3 weeks. For chondrogenic differentiation, passage 3 isolated cells were plated on 6-well culture plates at a density of $2.5 \times 10^{3}$ cells $/ \mathrm{cm}^{2}$, and after incubation in PM for $24 \mathrm{hr}$ the medium was changed to chondrogenic induction medium (Differentiation Basal Medium-Chondrogenic, Lonza) supplemented with $0.5 \mathrm{~g} / \mathrm{l}$ D-glucose, 350 $\mu \mathrm{M}$ L-proline, $100 \mathrm{nM}$ dexamethasone, and $0.02 \mathrm{~g} / l$ transforming growth factor TGF- $\beta 3$. The medium was changed 3 times per week. Alcian Blue staining was performed to analyze chondrogenic differentiation at 3 weeks. For adipogenic differentiation, passage 3 isolated cells were plated on 6 -well culture plates at a density of $1.5 \times 10^{4} \mathrm{cells} / \mathrm{cm}^{2}$, and after incubation in PM for $24 \mathrm{hr}$ the medium was changed to adipogenic induction medium (Differentiation Basal Medium-Adipogenic, Lonza) composed of DMEM supplemented with $4.5 \mathrm{~g} / l$ D-glucose, $100 \mu \mathrm{M}$ indomethacin, 10 $\mu \mathrm{g} / \mathrm{ml}$ insulin, $0.5 \mathrm{mM}$ 3-isobutyl-1-methylxanthine, $1 \mu \mathrm{M}$ dexamethasone, and 5\% rabbit serum. Oil Red $\mathrm{O}$ staining was performed to analyze adipogenic differentiation at 4 days. After osteogenic induction culture for 3 weeks, isolated cells produced a specific matrix, including calcium apatite crystals, which were positively stained with Alizarin
Red (Fig. 3b). After chondrogenic induction culture for 3 weeks, isolated cells aggregated and then contracted to form colonies that stained intensely with Alcian Blue (Fig. 3d). After adipogenic induction culture for 4 days, lipid droplets were detected by Oil Red O staining (Fig. 3f). The negative controls were cultured with PM during the corresponding periods of time taken to induce osteogenic, adipogenic, and chondrogenic differentiation (Fig. 3a, 3c, 3e). Minimal criteria of an MSC include capacity for trilineage differentiation into osteogenic, chondrogenic, and adipogenic lineages [6]. The isolated cells in this study satisfy one of the criteria.

For characterization of surface makers, cell surface antigen phenotyping was performed by flow cytometry. Passage 3 isolated cells $\left(2 \times 10^{5}\right.$ cells $)$ were resuspended in $500 \mu l$ FACS buffer (PBS containing 1\% sodium azide and $0.5 \% \mathrm{BSA}, \mathrm{pH} 7.2$ ). The cells were incubated with antibodies including CD34-FITC, CD45-FITC, CD90FITC (BD Biosciences, San Jose, CA, U.S.A.), CD44, CD105-FITC (AbD Serotec, Raleigh, NC, U.S.A.), CD11a/ CD18, and MHC Classes I and II (gifts from Dr. Douglas Antczak, Cornell University, Ithaca, New York) at $4{ }^{\circ} \mathrm{C}$ for $30 \mathrm{~min}$. The cells were washed twice with FACS buffer and resuspended in $500 \mu \mathrm{l}$ FACS buffer. The cells incubated with CD11a/CD18, CD44, and MHC Classes I and II were incubated with anti-mouse IgG secondary antibodies labeled with FITC (Rockland, Gilbertsville, PA, U.S.A.) at $4^{\circ} \mathrm{C}$ for $30 \mathrm{~min}$. Nonspecific FITC mouse immunoglobulin

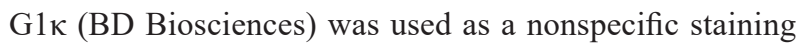
control. Cell fluorescence was evaluated by flow cytometry in a FACS Calibur instrument (BD Biosciences). Data were analyzed using CellQuest Pro software (BD Biosciences). The isolated cells expressed high levels of CD44 and CD90, low levels of CD11a/CD18, CD105, and MHC Class I. In contrast, CD34, CD45, and MHC Class II were not expressed (Fig. 4). The results for mesenchymal markers (positive for CD44, CD90, CD11a/CD18, and CD105) and hematopoietic makers (negative for CD34 and CD45) are similar to those of MSCs from various horse tissues [8, 16, 21]. On the other hand, expression of the MHC proteins was low for Class I and negative for Class II, and the intensity was lower than in previous equine MSCs studies $[8,16]$. As MHC proteins determine histocompatibility, Schnabel et al. reported that immune responses were not induced in MSCs not expressing MHC Class II in vitro [18]. From the above, we consider that the cells isolated in this study may be used for allotransplantation which can be transplanted to different individuals.

In conclusion, we successfully isolated self-replicating cells that fulfilled the minimal criteria for MSCs from Noma horse PB. Further, MSCs could be isolated from a precious native horse in a minimally invasive manner. In the future, 

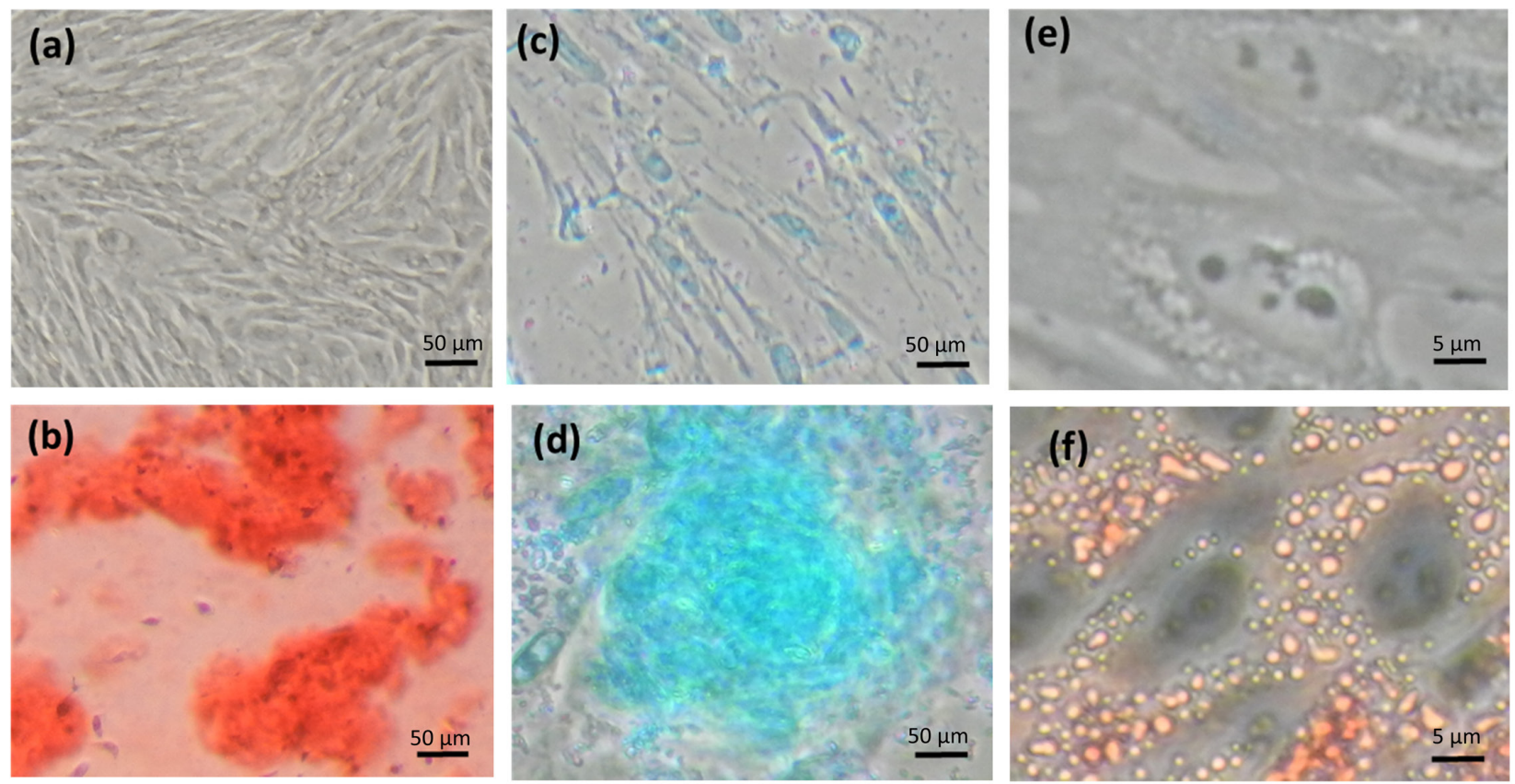

Fig. 3. Images of in vitro differentiation of isolated cells. Alizarin Red staining of control culture (a) and osteogenic induction (b). Alcian Blue staining of control culture (c) and chondrogenic induction (d). Oil Red O staining of control culture (e) and adipogenic induction (f).
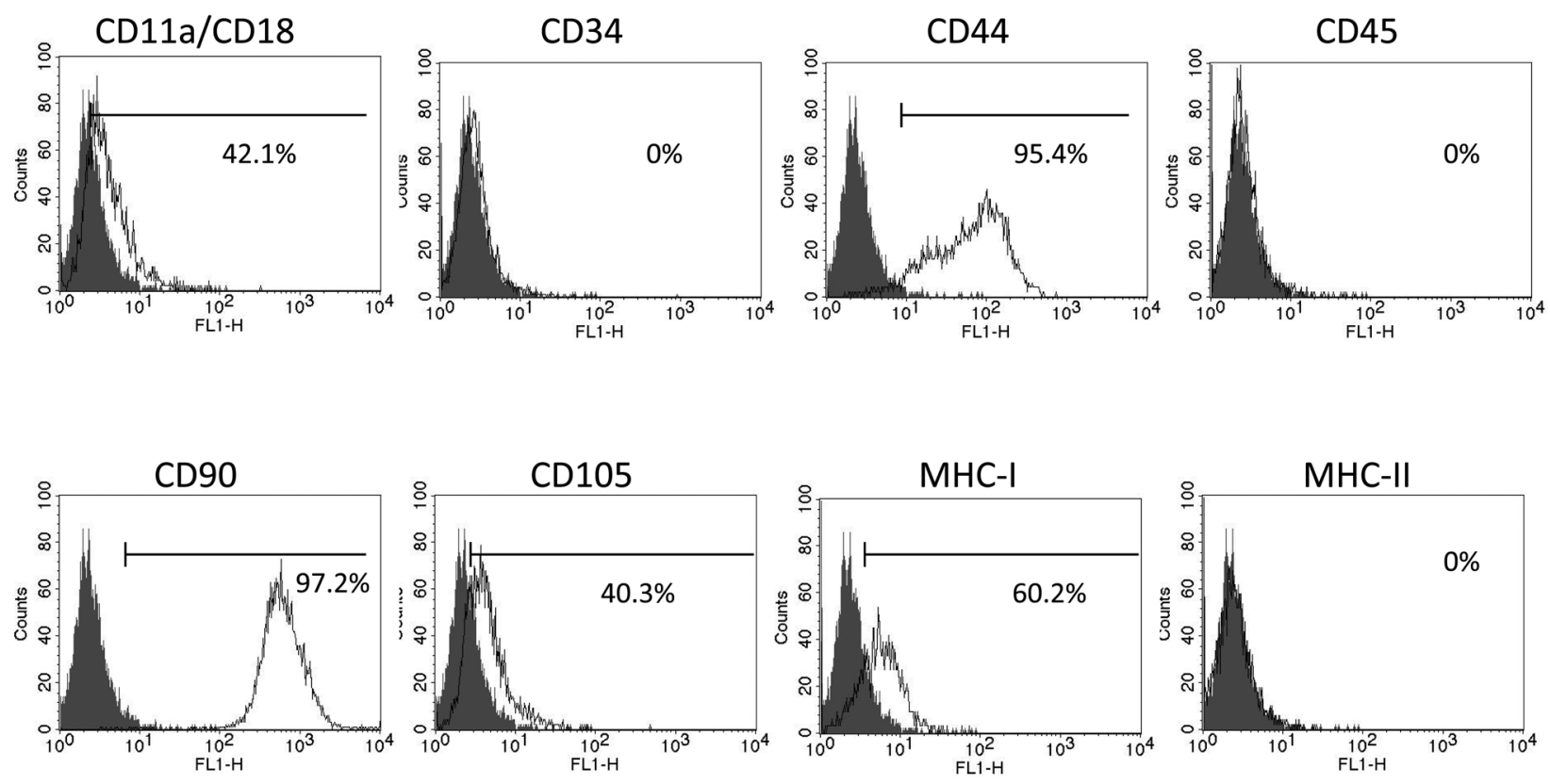

Fig. 4. Results of flow cytometry analysis of isolated cells. Solid histograms show nonspecific staining and open histograms show specific staining of the indicated marker. The signal intensity of the indicated antigen is presented as mean \pm standard deviation of triplicate experiments. 
we need to confirm whether MSCs from other individuals can be successfully isolated and need to study the usefulness for Japanese native horse preservation using PB-MSCs.

\section{Acknowledgments}

We are grateful to Drs. S. Nagata and H. Kakoi of the Laboratory of Racing Chemistry, Japan, for helpful discussions and technical advice and to Dr. Douglas Antczak, Mr. Donald Miller, and Ms Becky Harman for the gifts of the antibodies against CD11a/18, and MHC Classes I and II.

\section{References}

1. Alipour, F., Parham, A., Kazemi Mehrjerdi, H., and Dehghani, H. 2015. Equine adipose-derived mesenchymal stem cells: phenotype and growth characteristics, gene expression profile and differentiation potentials. Cell J. 16: 456-465. [Medline]

2. Braun, J., Hack, A., Weis-Klemm, M., Conrad, S., Treml, S., Kohler, K., Walliser, U., Skutella, T., and Aicher, W.K. 2010. Evaluation of the osteogenic and chondrogenic differentiation capacities of equine adipose tissue-derived mesenchymal stem cells. Am. J. Vet. Res. 71: 1228-1236. [Medline] [CrossRef]

3. Burk, J., Ribitsch, I., Gittel, C., Juelke, H., Kasper, C., Staszyk, C., and Brehm, W. 2013. Growth and differentiation characteristics of equine mesenchymal stromal cells derived from different sources. Vet. J. 195: 98-106. [Medline] [CrossRef]

4. Dennis, J.E., Merriam, A., Awadallah, A., Yoo, J.U., Johnstone, B., and Caplan, A.I. 1999. A quadripotential mesenchymal progenitor cell isolated from the marrow of an adult mouse. J. Bone Miner. Res. 14: 700-709. [Medline] [CrossRef]

5. Dhar, M., Neilsen, N., Beatty, K., Eaker, S., Adair, H., and Geiser, D. 2012. Equine peripheral blood-derived mesenchymal stem cells: isolation, identification, trilineage differentiation and effect of hyperbaric oxygen treatment. Equine Vet. J. 44: 600-605. [Medline] [CrossRef]

6. Dominici, M., Le Blanc, K., Mueller, I., Slaper-Cortenbach, I., Marini, F., Krause, D., Deans, R., Keating, A., Prockop, D., and Horwitz, E. 2006. Minimal criteria for defining multipotent mesenchymal stromal cells. The International Society for Cellular Therapy position statement. Cytotherapy 8: 315-317. [Medline] [CrossRef]

7. Horwitz, E.M., Prockop, D.J., Fitzpatrick, L.A., Koo, W.W., Gordon, P.L., Neel, M., Sussman, M., Orchard, P., Marx, J.C., Pyeritz, R.E., and Brenner, M.K. 1999. Transplantability and therapeutic effects of bone marrowderived mesenchymal cells in children with osteogenesis imperfecta. Nat. Med. 5: 309-313. [Medline] [CrossRef]

8. Ishikawa, S., Horinouchi, C., Murata, D., Matsuzaki, S., Misumi, K., Iwamoto, Y., Korosue, K., and Hobo, S. 2017.
Isolation and characterization of equine dental pulp stem cells derived from Thoroughbred wolf teeth. J. Vet. Med. Sci. 79: 47-51. [Medline] [CrossRef]

9. Johnstone, B., Hering, T.M., Caplan, A.I., Goldberg, V.M., and Yoo, J.U. 1998. In vitro chondrogenesis of bone marrow-derived mesenchymal progenitor cells. Exp. Cell Res. 238: 265-272. [Medline] [CrossRef]

10. Kakoi, H., Nagata, S., and Kurosawa, M. 2001. DNA typing with 17 microsatellites for parentage verification of racehorses in Japan. Anim. Sci. J. 72: 453.

11. Kasashima, Y., Ueno, T., Tomita, A., Goodship, A.E., and Smith, R.K. 2011. Optimisation of bone marrow aspiration from the equine sternum for the safe recovery of mesenchymal stem cells. Equine Vet. J. 43: 288-294. [Medline] [CrossRef]

12. Koerner, J., Nesic, D., Romero, J.D., Brehm, W., MainilVarlet, P., and Grogan, S.P. 2006. Equine peripheral bloodderived progenitors in comparison to bone marrow-derived mesenchymal stem cells. Stem Cells 24: 1613-1619. [Medline] [CrossRef]

13. Kopen, G.C., Prockop, D.J., and Phinney, D.G. 1999. Marrow stromal cells migrate throughout forebrain and cerebellum, and they differentiate into astrocytes after injection into neonatal mouse brains. Proc. Natl. Acad. Sci. U.S.A. 96: 10711-10716. [Medline] [CrossRef]

14. Lai, R.C., Arslan, F., Lee, M.M., Sze, N.S., Choo, A., Chen, T.S., Salto-Tellez, M., Timmers, L., Lee, C.N., El Oakley, R.M., Pasterkamp, G., de Kleijn, D.P., and Lim, S.K. 2010. Exosome secreted by MSC reduces myocardial ischemia/reperfusion injury. Stem Cell Res. (Amst.) 4: 214-222. [Medline] [CrossRef]

15. Matsubara, K., Matsushita, Y., Sakai, K., Kano, F., Kondo, M., Noda, M., Hashimoto, N., Imagama, S., Ishiguro, N., Suzumura, A., Ueda, M., Furukawa, K., and Yamamoto, A. 2015. Secreted ectodomain of sialic acid-binding Ig-like lectin-9 and monocyte chemoattractant protein-1 promote recovery after rat spinal cord injury by altering macrophage polarity. J. Neurosci. 35: 2452-2464. [Medline] [CrossRef]

16. Murata, D., Miyakoshi, D., Hatazoe, T., Miura, N., Tokunaga, S., Fujiki, M., Nakayama, K., and Misumi, K. 2014. Multipotency of equine mesenchymal stem cells derived from synovial fluid. Vet. J. 202: 53-61. [Medline] [CrossRef]

17. Nayernia, K., Lee, J.H., Drusenheimer, N., Nolte, J., Wulf, G., Dressel, R., Gromoll, J., and Engel, W. 2006. Derivation of male germ cells from bone marrow stem cells. $L a b$. Invest. 86: 654-663. [Medline] [CrossRef]

18. Schnabel, L.V., Pezzanite, L.M., Antczak, D.F., Felippe, M.J., and Fortier, L.A. 2014. Equine bone marrow-derived mesenchymal stromal cells are heterogeneous in $\mathrm{MHC}$ class II expression and capable of inciting an immune response in vitro. Stem Cell Res. Ther. 5: 13. [Medline] [CrossRef] 
19. Sherman, A.B., Gilger, B.C., Berglund, A.K., and Schnabel, L.V. 2017. Effect of bone marrow-derived mesenchymal stem cells and stem cell supernatant on equine corneal wound healing in vitro. Stem Cell Res. Ther. 8: 120. [Medline] [CrossRef]

20. Smith, R.K., Korda, M., Blunn, G.W., and Goodship, A.E. 2003. Isolation and implantation of autologous equine mesenchymal stem cells from bone marrow into the superficial digital flexor tendon as a potential novel treatment. Equine Vet. J. 35: 99-102. [Medline] [CrossRef]

21. Spaas, J.H., Gambacurta, A., Polettini, M., Broeckx, S., Van Hoeck, F., De Schauwer, C., Van De Walle, G.R., and Van Soom, A. 2011. Purification and expansion of stem cells from equine peripheral blood, with clinical applications. Vlaams Diergeneeskundig Tijdschr. 80: 129-135.
22. Tozaki, T., Kakoi, H., Mashima, S., Hirota, K., Hasegawa, T., Ishida, N., Miura, N., Choi-Miura, N.H., and Tomita, M. 2001. Population study and validation of paternity testing for Thoroughbred horses by 15 microsatellite loci. $J$. Vet. Med. Sci. 63: 1191-1197. [Medline] [CrossRef]

23. Tozaki, T., Takezaki, N., Hasegawa, T., Ishida, N., Kurosawa, M., Tomita, M., Saitou, N., and Mukoyama, H. 2003. Microsatellite variation in Japanese and Asian horses and their phylogenetic relationship using a European horse outgroup. J. Hered. 94: 374-380. [Medline] [CrossRef]

24. Violini, S., Ramelli, P., Pisani, L.F., Gorni, C., and Mariani, P. 2009. Horse bone marrow mesenchymal stem cells express embryo stem cell markers and show the ability for tenogenic differentiation by in vitro exposure to BMP-12. BMC Cell Biol. 10: 29. [Medline] [CrossRef] 